\title{
Cost-Effectiveness of Caries Prevention in Practice: A Randomized Controlled Trial.
}

DOI:

10.1177/0022034517708968

\section{Document Version}

Accepted author manuscript

Link to publication record in Manchester Research Explorer

\section{Citation for published version (APA):}

O'Neill, C., Worthington, H., Donaldson, M., Birch, S., Noble, S., Killough, S., Murphy, L., Greer, M., Brodison, J., Verghis, R., \& Tickle, M. (2017). Cost-Effectiveness of Caries Prevention in Practice: A Randomized Controlled Trial. Journal of Dental Research, 96(8), 875-880. https://doi.org/10.1177/0022034517708968

\section{Published in:}

Journal of Dental Research

\section{Citing this paper}

Please note that where the full-text provided on Manchester Research Explorer is the Author Accepted Manuscript or Proof version this may differ from the final Published version. If citing, it is advised that you check and use the publisher's definitive version.

\section{General rights}

Copyright and moral rights for the publications made accessible in the Research Explorer are retained by the authors and/or other copyright owners and it is a condition of accessing publications that users recognise and abide by the legal requirements associated with these rights.

\section{Takedown policy}

If you believe that this document breaches copyright please refer to the University of Manchester's Takedown Procedures [http://man.ac.uk/04Y6Bo] or contact uml.scholarlycommunications@manchester.ac.uk providing relevant details, so we can investigate your claim.

\section{OPEN ACCESS}




\section{Journal of \\ Dental Research}

\section{Cost-effectiveness of caries prevention in practice: randomised trial}

\begin{tabular}{|c|c|}
\hline Journal: & Journal of Dental Research \\
\hline Manuscript ID & JDR-16-1278.R2 \\
\hline Manuscript Type: & Research Reports \\
\hline Date Submitted by the Author: & $n / a$ \\
\hline Complete List of Authors: & $\begin{array}{l}\text { O'Neill, Ciaran; Queen's University Belfast, Centre for Public Health } \\
\text { Worthington, Helen; The University of Manchester, School of Dentistry } \\
\text { Donaldson, Michael; Health and Social Care Board } \\
\text { Birch, Stephen; The University of Manchester } \\
\text { Noble, Solveig; Braid Valley Hospital, Community Dental Department } \\
\text { Killough, Seamus; British Dental Association Northern Ireland, The Mount } \\
\text { Business Centre } \\
\text { Murphy, Lynn; Belfast Health and Social Care Trust, Northern Ireland } \\
\text { Clinical Trials Unit } \\
\text { Greer, Margaret; Queen Mary BioEnterprises Innovation Centre, hVIVo } \\
\text { Brodison, Julie; DJ Maguire and Associates } \\
\text { Verghis, Rejina; Belfast Health and Social Care Trust, Northern Ireland } \\
\text { Clinical Trials Unit } \\
\text { Tickle, Martin; Manchester University Dental School, Oral Health Unit }\end{array}$ \\
\hline Keywords: & $\begin{array}{l}\text { Economic evaluation, Clinical studies/trials, Comparative effectiveness } \\
\text { research (CER), Child Dentistry, Fluoride(s) }\end{array}$ \\
\hline Abstract: & $\begin{array}{l}\text { Background: Two-arm parallel group randomized controlled trial to } \\
\text { measure the cost-effectiveness of caries prevention in caries-free children } \\
\text { aged } 2-3 \text { years attending general practice. } \\
\text { Methods: The setting was } 22 \text { dental practices in Northern Ireland. } \\
\text { Participants were centrally randomized into intervention: } 22,600 \text { ppm } \\
\text { fluoride varnish; toothbrush; } 50 \mathrm{ml} \text { tube of } 1,450 \text { ppm fluoride toothpaste; } \\
\text { and standardised prevention advice, and control: advice-only, both } \\
\text { provided at } 6 \text {-monthly intervals during } 3 \text {-year follow-up. The primary } \\
\text { outcome measure was conversion from caries-free to caries-active states } \\
\text { assessed by calibrated and blinded examiners; secondary outcome } \\
\text { measures included dmfs, pain and extraction. Cumulative costs were } \\
\text { related to each of the trial's outcomes in a series of incremental cost } \\
\text { effectiveness ratios (ICERs). Sensitivity analyses examined the impact of } \\
\text { using dentist's time as measured by observation rather than that reported } \\
\text { by the dentist. The costs of applying topical fluoride were also estimated } \\
\text { assuming the work was undertaken by dental nurses or hygienists rather } \\
\text { than dentists. } \\
\text { Results: A total of } 1248 \text { children (624 randomised to each group) were }\end{array}$ \\
\hline
\end{tabular}


recruited and 1096 (549 in the intervention group and 547 in the control group) were included in the final analyses. The mean difference in direct healthcare costs between groups was $£ 107.53$ ( $£ 155.74$ intervention, $£ 48.21$ control, $\mathrm{P}<0.05)$ per child. When all healthcare costs were compared the intervention group's mean cost was $£ 212.56$ more than the control group ( $£ 987.53$ intervention, $£ 774.97$ control, $P<0.05$ ). Statistically significant differences in outcomes were only detected in respect of carious surfaces. The mean cost per carious surface avoided was estimated at $£ 251$ ( $95 \%$ CI $£ 454.39$ - $€ 79.52)$. Sensitivity analyses did not materially affect the study's findings.

Conclusions: This trial raises concerns about the cost-effectiveness of a fluoride-based intervention delivered at the practice level in the context of a state-funded dental service.

Trial registration: details

EudraCT No: 2009-010725-39

ISRCTN: ISRCTN3618011

\section{SCHOLARONEm \\ Manuscripts}


Title: Cost-effectiveness of caries prevention in practice: randomized controlled trial

C O’Neill ${ }^{1}$, HV Worthington ${ }^{2}, \mathrm{M}$ Donaldson ${ }^{3}, \mathrm{~S} \mathrm{Birch}^{4,9}, \mathrm{~S} \mathrm{Noble}^{5}, \mathrm{~S} \mathrm{Killough}^{6}$, L Murphy $^{7}$, M Greer ${ }^{8}$, J Brodison ${ }^{7}$, R Verghis $^{7}$, M Tickle $^{2}$

1. Centre for Public Health, Queen's University Belfast, UK

2. Division of Dentistry, School of Medical Sciences, Faculty of Biology, Medicine and Health, University of Manchester, UK

3. Health \& Social Care Board of Northern Ireland

4. School of Health Sciences, Faculty of Biology, Medicine and Health, University of Manchester, UK

5. Northern Health \& Social Care Trust, Northern Ireland

6. British Dental Association, Belfast, Northern Ireland

7. Northern Ireland Clinical Trials Unit, Belfast Health \& Social Care Trust, Northern Ireland

8. hVIVO, Queen Mary BioEnterprises Innovation Centre, London, UK

9. Centre for Health Economics and Policy Analysis, McMaster University, Canada

Corresponding author: Professor Martin Tickle, University of Manchester e-mail martin.tickle@manchester.ac.uk

Abstract word count: 297

Total word count (excluding Abstract and acknowledgments): 3174

Total number of tables/figures: 5

Number of references: 23

Key words: Economic evaluation, Clinical studies/trials, Comparative effectiveness research (CER), Child Dentistry, Fluoride(s), Clinical Practice 


\section{Abstract}

Background: Two-arm parallel group randomized controlled trial to measure the cost-effectiveness of caries prevention in caries-free children aged 2-3 years attending general practice.

Methods: The setting was 22 dental practices in Northern Ireland.

Participants were centrally randomized into intervention: 22,600 ppm

fluoride varnish; toothbrush; $50 \mathrm{ml}$ tube of 1,450 ppm fluoride toothpaste;

and standardised prevention advice, and control: advice-only, both

provided at 6-monthly intervals during 3-year follow-up. The primary

outcome measure was conversion from caries-free to caries-active states assessed by calibrated and blinded examiners; secondary outcome measures included dmfs, pain and extraction. Cumulative costs were related to each of the trial's outcomes in a series of incremental cost effectiveness ratios (ICERs). Sensitivity analyses examined the impact of using dentist's time as measured by observation rather than that reported by the dentist. The costs of applying topical fluoride were also estimated assuming the work was undertaken by dental nurses or hygienists rather than dentists.

Results: A total of 1248 children (624 randomised to each group) were recruited and 1096 (549 in the intervention group and 547 in the control group) were included in the final analyses. The mean difference in direct healthcare costs between groups was $£ 107.53$ (£155.74 intervention, $£ 48.21$ control, $P<0.05)$ per child. When all healthcare costs were compared the intervention group’s mean cost was $£ 212.56$ more than the control group (£987.53 intervention, $£ 774.97$ control, $P<0.05$ ). Statistically 
significant differences in outcomes were only detected in respect of carious surfaces. The mean cost per carious surface avoided was estimated at $£ 251$ (95\% Cl £454.39 - £79.52). Sensitivity analyses did not materially affect the study's findings.

Conclusions: This trial raises concerns about the cost-effectiveness of a fluoride-based intervention delivered at the practice level in the context of a state-funded dental service.

Trial registration: details

EudraCT No: 2009-010725-39

ISRCTN: ISRCTN36180119 


\section{Introduction}

Dental caries is the commonest disease of childhood (NIH 2000). Once caries develops in young children it progresses rapidly, (Milsom et al. 2008) commonly results in pain and extraction, (Tickle et al. 2008) has a negative impact on families (M-L Mattila et al. 2000) and incurs significant costs for healthcare systems (Casamassimo et al. 2009).

Prevention of the disease is seen as a more affordable option than treatment of established disease (CDC 2009). Cochrane reviews provide strong evidence to demonstrate the effectiveness of fluoride delivered in various guises to prevent caries (Marinho et al. 2003, 2004, 2013). However, the reviews provide little information on the cost-effectiveness of these interventions. Comparable cost-effectiveness information is important to enable objective assessment of the relative return on investment of different caries prevention options.

We undertook a large trial to measure the effects and costs of a combined fluoride intervention designed to prevent caries in young children attending dental services. The clinical outcomes of the intervention are presented elsewhere. (Tickle et al. 2016; Tickle et al. 2017) This paper reports the costeffectiveness of the intervention and discusses the difficulties of establishing whether or not the outcomes represent value for money.

\section{Methods}


This was a two-arm, parallel group randomised controlled trial with an allocation ratio of 1:1. The trial protocol was published in 2011 prior to recruitment, (Tickle et al. 2011) and no important changes were made after trial commencement. Greater Manchester Central Research Ethics Committee provided ethical approval and oversight (reference 09/H1008/93). The trial was registered as a Clinical Trial of an Investigative Medicinal Product (CTIMP) with the Medicines \& Healthcare products Regulatory Agency (MHRA).

The study population were children aged 2-3 years who were registered with 22 NHS General Dental Practices in Northern Ireland. At the time of planning the trial 61 per cent of 5-year-olds in Northern Ireland had caries (Lader D. et al. 2005). Children were eligible for inclusion if they were: 2 or 3 but not yet 4 years-old and caries (into dentine) free at baseline, including no history of fillings or extractions due to caries. Exclusion criteria included presence of fissure sealants on primary molar teeth and a history of severe allergic reactions. The Belfast Clinical Trials Unit (CTU) centrally randomised children by a computer generated randomisation schedule for each practice, using randomised permutated blocks. The intervention consisted of:

- $22,600 \mathrm{ppm}$ of fluoride varnish applied to all primary teeth by the children's dentist

- $\quad$ a free toothbrush and $50 \mathrm{ml}$ tube of 1,450 ppm of fluoride toothpaste. 
- $\quad$ Standardised dental health education on optimal use of fluoride toothpaste and restriction of sugar consumption.

The intervention was provided at the child's dental check-up, twice a year at approximately 6-month intervals. The control group received the same standardised dental health education as the intervention group, every 6 months at their dental check-up. As the effectiveness of health education may be conditioned on other actions that accompany it, the check-up was consciously included among activities provided to both control and intervention groups. Participants were followed-up for 3 years. The primary outcome measure was conversion from caries-free to caries-active states. Secondary outcome measures included the mean number of decayed, missing or filled teeth surfaces (dmfs) in children with caries, number of episodes of pain, number of extractions and costs. Caries severity (dmfs) was also calculated for the whole sample. Children were enrolled into the trial and caries outcomes were assessed in the practices by 12 trained and calibrated (Intra- and inter-examiner agreements kappa scores $>0.70$ see Appendix Table 1) dentists from the Community Dental Service, who were blind to the allocation. The sample size calculation is described in the protocol (Tickle et al. 2011) and discussed in the report of clinical findings (Tickle et al. 2017). Costs data collected included:

- $\quad$ The market costs of varnish, toothpaste and toothbrushes collected by reference to the providing manufacturer

- $\quad$ Time taken to deliver the intervention calculated from data gathered via the Case Report Form (CRF), a paper record, completed at each of the 6monthly scheduled visits by site research assistants and validated by an 
observed time and motion study conducted in a sample of practices. The delivery time was monetised by reference to implicit average NHS dental pay rates provided by the NHS Central Services Agency. Other dental treatments provided by trial or other dentists, in addition to the 6-monthly scheduled visits, were also captured in the CRF. Unit costs were applied to these based on the NHS Statement of Dental Remuneration (SDR) 2014/15 (NIH\&SCB 2014) taken as reflecting the opportunity cost associated with provision of the dental activity in question.

- Utilisation of other healthcare services was collected using a parental questionnaire, capturing details of General Practitioner (family doctor) visits, hospital inpatient days, outpatient visits and emergency room visits. Unit costs in respect of these services were taken from standard UK references (Curtis 2014, DH 2015).

- Measurement of non-healthcare costs included reported total time taken to accompany the child for a dental visit, including time off work plus distance travelled. This was measured via the parental questionnaire. Travel costs were monetised using Automobile Association (AA 2014) reference costs per mile (as approximately $90 \%$ of parents travelled by car in both groups - the remainder by foot or bus - all parents' travel costs were monetised assuming private vehicle use). Parental time costs were monetised using average earnings in Northern Ireland. Appendix Table 4 summarizes the data collected and the monetisation source.

The economic analysis compared the mean cumulative costs per child incurred over the 3 year period in each arm of the trial and related these to the 
primary and secondary outcomes achieved over the same period. NHS costs were subdivided into those related to the intervention, those associated with other oral healthcare (check-ups, pulpectomies, etc.) and those associated with care provided by other health service professionals. For the intervention group direct intervention costs comprised of toothpaste and toothbrushes, fluoride varnish and the time involved in applying fluoride varnish, as well as a dental check-up during the course of which the varnish was applied. In the control group the 6-monthly visit to the dentist was treated as a check-up for cost purposes. Given the relatively short duration of the study, neither costs nor outcomes were discounted.

The analysis compared the total NHS costs in each of the two arms of the trial in accordance with the levels of effectiveness for each arm. In additional analyses, parental costs were added to those falling on the NHS. Incremental cost-effectiveness ratios (ICERs) were calculated to provide an estimate of the mean cost per additional unit of outcome. The ICERs were estimated following a bootstrapping exercise in which sample data were used to construct a sampling distribution of mean costs, effects, incremental costs and effects and ICERs. Net-monetary benefits (NMBs) were also calculated. In the absence of a threshold willingness to pay for the various measures of effect, a threshold of $£ 1000$ was assumed for each. Cost-effectiveness acceptability curves were generated in respect of each outcome to examine uncertainty around the threshold. 
A series of sensitivity analyses were undertaken. These included reestimations of cost-effectiveness when:

- $\quad$ parental costs were included

- $\quad$ measured delivery time (from the time and motion study) as opposed to that reported by dentists

- $\quad$ fluoride was assumed to have been applied by a dental nurse or a hygienist rather than a dentist

- $\quad$ costs were examined solely from the perspective of a dental care service, ignoring parental costs or costs to other parts of the health service. 


\section{Results}

The CONSORT flow diagram (Appendix Figure 1), baseline characteristics (Appendix Table 2) and the clinical findings (Appendix Table 3) are presented elsewhere (Tickle et al. 2017) We found a 5 per cent difference in caries prevalence (primary outcome) between the groups in favour of the intervention, but this was not statistically significant. For secondary outcomes, differences in episodes of pain $(P=0.81)$ and number of teeth extracted were not significant $(P=0.95)$. Secondary caries outcome measures $(\mathrm{dmfs})$ showed a significant difference in favour of the intervention group. Among the full sample the intervention group had on average 1.3 fewer carious surfaces than the control group. Compliance was high, 87 per cent of intervention and 86 per cent of control children attended every 6-month visit $(P=0.77)$.

The appendix contains tables presenting details of

- $\quad$ intervention costs and the costs associated with scheduled check-ups among the control group. The largest element of cost in the intervention group was time taken to apply fluoride (delivery time) which in this analysis is based on time taken as reported by the dentist.

- $\quad$ other NHS healthcare costs. The control group has significantly larger costs associated with restorations and extractions for example. In respect of other healthcare costs, no statistically significant differences in cost were evident.

- $\quad$ No statistically significant differences in costs incurred by parents associated with the consumption of dental care were found. 
Table 1 compares the total costs of these three elements combined; the total direct healthcare costs associated with the intervention, total indirect healthcare costs and total parental costs together with differences between the two arms of the study. All costs are based on the cumulative use of services over the three-year follow-up and expressed on a per person basis. In respect of direct costs, total healthcare costs and total costs, statistically significant between group differences were evident. In each case the intervention group had higher costs though as is evident from Appendix Tables 5 to 7 , this was largely related to the cost of the intervention.

In Table 2 a series of ICERs are reported together with associated 95\% confidence intervals. ICERs are reported for three outcome measures, caries free status, carious surfaces and episodes of pain. In each case the negative ICER should be interpreted as the mean additional cost per outcome avoided. For example, in respect of caries free status, it costs on average approximately £2093 for every child prevented from converting to caries; in respect of carious surfaces it costs on average approximately $£ 251$ for every carious surface prevented. The only statistically significant results were obtained in respect of carious surfaces, which reflects the results of the clinical analysis (Tickle et al 2017).

Table 3 presents a series of NMB estimates, each predicated on the assumption that society would be willing to pay $£ 1000$ for every unit of the outcome in question. As with Table 2, a positive NMB was found only in 
respect of carious surfaces. This suggests that if society was willing to pay $£ 1000$ per carious surface avoided, the intervention would deliver a net monetary benefit of approximately $£ 1063$ per carious surface avoided when the intervention and other costs associated with its generation are taken into consideration. While the 95 per cent confidence interval around this value is positive, it is quite wide-ranging from $£ 298$ to $£ 1855$.

Cost-effectiveness planes and cost-effectiveness acceptability curves (CEACs) in respect of each outcome were also derived. Only those in respect of carious surfaces are reported here. The appearance of the former (Figure 1) in the northwest quadrant of the diagram - higher cost, negative outcome simply reflects the structure of the outcome; that is carious surfaces avoided. In respect of the CEACs the likelihood of the intervention being deemed costeffective is highest in respect of carious surfaces avoided, which is consistent with the results of previous analyses. (Figure 2)

Appendix Tables 8, 9 and 10 present the results of a series of sensitivity analyses. Dentists consistently overestimated delivery time and adjusting for this reduced the intervention costs but did not have a material effect on costeffectiveness nor on NMB. Similar results were obtained in respect of other sensitivity analyses based on using nurses or hygienists to apply fluoride and limiting the focus of the analyses solely to dental costs. The reduction in staff costs (and exclusion of other healthcare costs) improved the costeffectiveness ratio and NMB calculation but the intervention remained potentially cost-effective only in respect of reducing carious surfaces. 


\section{Discussion}

The perspective adopted in our evaluation was that of the public payer. Given the finding of a small but statistically significant reduction in dmfs, the economic analyses were important to establish if the effect size justified the investment required producing it. The costs of care in the intervention group were significantly greater than for the control group over the three-year period. For total direct dental service costs per child (Table 1) there was a mean difference over the 3 -years of the study of $£ 107.53$ ( $£ 155.74$ intervention, $£ 48.21$ control, $P<0.05)$. When all health care costs were compared the intervention group's mean cost per child was $£ 212.56$ more that the control group ( $£ 987.53$ intervention, $£ 774.97$ control, $P<0.05$ ). The mean cost per carious surface avoided after 3 years was estimated at $£ 251$ with a wide 95 per cent confidence interval (£454.39 to $£ 79.52)$.

It is important to recognise that our analyses did not include financial incentives paid to dentists to provide preventive care, or the costs of performance management of practices to ensure that prevention was delivered to a minimum standard. In the trial, the practices received a $£ 25$ payment for each visit of each child to cover the costs of hosting the trial. The stringent trial monitoring processes required of a CTIMP ensured fidelity to the protocol was tightly monitored. So there were in-built incentives for practices to increase retention and adherence. These costs were not included in the economic analyses, as they were part of the trial infrastructure. If the intervention tested were to be translated into a NHS service, consideration 
would need to be given to these potential incentives and their attendant costs if the adherence rates we report are to be achieved, which would increase the costs of the intervention substantially.

The discrepancy between the time dentists reported taking to apply fluoride and that recorded in the time and motion study is also noteworthy in this regard. While the difference had no material effect on cost-effectiveness, it highlights the difference between perceptions among dentists and actual time used. Given the intervention's potential to displace other income generating activity, adopting the intervention may require incentives that reflect dentists' perceptions of timings rather than those captured in the time and motion study.

Other factors could reduce the costs of the intervention, for example use of role substitution by employing appropriately trained mid-level providers (Dyer et al. 2014). In the sensitivity analyses we substituted the salary costs of a dentist with hygienists or dental nurses. The mean direct dental costs of using dental nurses (£74.57) and hygienists (£106.37) to deliver the intervention were lower than costs of using dentists (£155.74). However, this was based on the assumption that time required to deliver the intervention was the same for each type of provider. It also does not account for restrictions on scope of practice. In a number of countries mid-level providers cannot diagnose dental disease or prescribe fluoride varnish and so separate visits to different healthcare professionals for assessment, diagnosis and prescription would be 
required. In this scenario mid-level provider costs would be supplementary to, rather than substituting the dentist's costs.

Our findings only report the costs and effects over a three-year period, and do not reflect outcomes throughout later childhood, or indeed over the whole life course. A recent longitudinal cohort study reported (Hall-Scullin et al. 2017) children with caries in their primary teeth were five times more likely to develop caries in their permanent teeth than children whose primary dentition was caries-free. This study illustrates the consequences of developing caries in early childhood has effects across the life course, however, there are significant barriers to produce credible life-time costs and benefits estimates for such a young population.

The study could not refer to a commonly used threshold mean willingness-topay for effects against which to assess the value for money of the intervention. This limitation was imposed on the study by our inability to directly assess the utility gain (if any) associated with caries prevention. We could not, in consequence, assess value for money relative to thresholds frequently reported in the literature. Moreover, it is unlikely that mean willingness-to-pay is constant for any gain in effectiveness, given that differences in the scale of an intervention will have different opportunity costs. Views on mean willingness-to-pay for an avoided carious surface or per child remaining caries free are likely to be very different for different sectors of society. Our calculations of NMB are based on an assumed willingness to pay 
per carious surface avoided of $£ 1000$. The cost to repair a carious surface is a fraction of this [NHS costs of a restoration in Northern Ireland = £8.30](NIH\&SCB 2014). Whether in such circumstances prevention offers better value than repair is open to debate. Furthermore there is uncertainty about how long the benefit we report would be sustained for beyond the 3years follow up.

Interventions delivered in general practice, perversely, may increase inequalities, as many children living in the most disadvantaged communities access dental services sporadically (Ravaghi et al. 2015). Other communitybased interventions may provide better population health outcomes at lower cost. A systematic review (Mariño et al. 2013) of the economic evaluation of caries prevention programmes included a total of 63 studies, evaluating dental sealants, water fluoridation and mixed interventions. The review could not make firm conclusions, due to the limitations of the included studies; it is therefore difficult to compare the cost-effectiveness of the intervention we evaluated with alternative prevention strategies.

There are limitations to our study. We did not have information on oral hygiene habits at home nor exposure to sugar and therefore could not control for this in our analyses. Our choice of primary outcome is a universally accepted threshold for clinical intervention. While other outcomes could have been used, for example, the ICDS index (Ismail A. et al. 2007), our results with respect to carious surfaces and episodes of pain as well as sensitivity analyses around resource use, suggest our findings are likely to be robust 
across a range of reasonable alternative scenarios. We do not have demonstrably robust instruments to predict caries risk in a general practice setting for children who are caries free (Mejàre et al. 2014). If risk assessment tools (potentially including assessment of early enamel lesions) for use in general practice are refined and high levels of precision can be demonstrated this could have a positive impact on cost effectiveness, in that those at greatest risk could be targeted for the intervention. Conversely it could have a negative effect on cost-effectiveness, as applying a complex risk assessment tool would add additional costs in terms of staff time.

In conclusion the costs of providing this preventive intervention outweighed savings in treatment over the 3-year follow up period. This intervention delivered in general dental practice is unlikely to produce a cost-saving for the NHS. Even with this evidence-based intervention and high levels of adherence, over a third of children developed caries. This finding, allied to the high costs of providing prevention in practice does not make a convincing argument for policy makers to invest in this technology. Other interventions, delivered in other settings may produce greater improvements in population health for lower costs.

\section{ACKNOWLEDGEMENTS}

This project was funded by the National Institute for Health Research Health Technology Assessment programme (project number 08/14/19). The views expressed are those of the authors and not necessarily those of the NHS, the NIHR or the Department of Health. 
We would like to thanks the practice principals and staff of the 22 Dental Practices involved in the trial, CDS Dentists who undertook the baseline and outcome examinations, the Health and Social Care Board of Northern Ireland, the 5 Health and Social Care (HSC) Trusts of Northern Ireland: Belfast HSC Trust, South Eastern HSC Trust, Western HSC Trust, Southern HSC Trust and Northern HSC Trust, the Department of Health, Social Services and Public Safety, former Chief Dental Officer Donncha O'Carolan, Simon Reid Chief Dental Officer, Members of the Trial Steering Group chaired by Professor Donald Burden, Members of the Independent Data Monitoring and Ethics Committee chaired by Professor Jan Clarkson and latterly by Professor Ivor Chestnutt, the staff of The Northern Ireland Clinical Trials Unit and PPI group chaired by Carolyn Slee.

Martin Tickle reports provision of free toothpaste and toothbrushes from Colgate-Palmolive for the trial. Seamus Killough was chairperson of the Northern Ireland Council of the British Dental Association throughout this trial. The other authors have no known conflicts of interest 


\section{References}

Automobile Association. AA Motoring Costs 2014. c2014. Basingstoke

(Hampshire). Automobile Association Developments Limited. [accessed 2016

December 14]. http://www.theaa.com/resources/Documents/pdf/motoringadvice/running-costs/petrol2014.pdf.

Casamassimo PS, Thikkurissy S, Edelstein BL, Maiorini E. 2009. Beyond the dmft: The Human and Economic Cost of Early Childhood Caries. J Am Dent Assoc. 140(6):650-657.

Centers for Disease Control and Prevention. 2009. The Power of Prevention: Chronic Disease... The Public Health Challenge of the 21st Century. Atlanta, GA: Centers for Disease Control and Prevention.

Curtis L. 2014. Unit Costs of Health and Social Care. Canterbury: Personal Social Services Research Unit, University of Kent. [accessed December 14, 2016] http://www.pssru.ac.uk/project-pages/unit-costs/2014/

Dyer TA, Brocklehurst P, Glenny AM, Davies L, Tickle M, Issac A, Robinson PG. 2014. Dental auxiliaries for dental care traditionally provided by dentists. Cochrane Database Syst Rev. 8:CD010076. DOI:

10.1002/14651858.CD010076.pub2. 
Hall-Scullin E, Whitehead H, Milsom KM, Tickle M, Su T-L, Walsh T. 2017

Longitudinal study of caries development from childhood through to

adolescence. J Dent Res. https://doi.org/10.1177/0022034517696457

Ismail A, Sohn W, Tellez M, Amaya A, Sen A, Hasson H, Pitts NB. 2007. The International Caries Detection and Assessment System (ICDAS). Community Dent Oral Epidemiol. 35(3):170-8.

Lader D, Chadwick B, Chestnutt I, Hawker R, Morris J, Nuttall N, Pitts NB, Steele J, White D. 2005. Children's Dental Health in the UK 2003. London. Office for National Statistics.

Marinho VCC, Higgins JPT, Logan S, Sheiham A. 2003. Fluoride toothpastes for preventing dental caries in children and adolescents. Cochrane Database Syst Rev. 1:CD002278. DOI: 10.1002/14651858.CD002278.

Marinho VCC, Higgins JPT, Sheiham A, Logan S. Combinations of topical fluoride (toothpastes, mouth rinses, gels, varnishes) versus single topical fluoride for preventing dental caries in children and adolescents. 2004. Cochrane Database Syst Rev. 1:CD002781. DOI:

10.1002/14651858.CD002781.pub2

\author{
Marinho VC, Worthington HV, Walsh T, Clarkson JE. 2013. Fluoride varnishes \\ for preventing dental caries in children and adolescents. Cochrane Database \\ Syst Rev. 7:CD002279. DOI: 10.1002/14651858.CD002279.pub2.
}


Mariño RJ, Khan AR, Morgan M. 2013. Systematic review of publications on economic evaluations of caries prevention programs. Caries Res. 47(4):26572.

Mejàre I, Axelsson S, Dahlén G, Espelid I, Norlund A, Tranæus S, Twetman S. Caries risk assessment. A systematic review. 2014. Acta Odontol Scand. 72(2):81-91. Epub 2013 Sep 2.

Milsom KM, Blinkhorn AS, Tickle M. 2008. The incidence of dental caries in the primary molar teeth of young children receiving National Health Service funded dental care in practices in the North West of England. Br Dent J. 205(7):E14.

Mattila M-L, Rautava P, Sillanpää M, Paunio P. 2000. Caries in Five-year-old Children and Associations with Family-related Factors. J Dent Res. 79(3):875881.

Oral health in America: a report of the Surgeon General. 2000. Rockville (MD): National Institute of Dental and Craniofacial Research, National Institutes of Health, U.S. Department of Health and Human Services. [accessed December 14, 2016]. https://www.nidcr.nih.gov/DataStatistics/SurgeonGeneral/Documents/hck1ocv @www.surgeon.fullrpt.pdf 
Ravaghi V, Hill K, Ryan R, Dennes M. 2015. Children's Dental Health Survey 2013. Country Specific Report: Northern Ireland. London: The Health and Social Care Information Centre. [accessed December 14, 2016]. http://www.hscic.gov.uk/catalogue/PUB17137/CDHS2013-Northern-IrelandReport.pdf (accessed August 2015).

Statement of Dental Remuneration 2014/15. 2015 Belfast: Business Services Organisation, Northern Ireland Health \& Social Care Board. [accessed December 14, 2016]. http://www.hscbusiness.hscni.net/2069.htm

Tickle M, Blinkhorn AS, Milsom KM. 2008. The occurrence of dental pain and extractions over a 3-year period in a cohort of children aged 3-6 years. J Public Health Dent. 68(2):63-69.

Tickle M, Milsom KM, Donaldson M, Killough S, O’ Neill C, Crealey G, Sutton M, Noble S, Greer M, Worthington HV. 2011. Protocol for Northern Ireland Caries Prevention in Practice Trial (NIC-PIP) trial: a randomised controlled trial to measure the effects and costs of a dental caries prevention regime for young children attending primary care dental services. BMC Oral Health. [accessed 2016 December 14] 11:27. http://dx.doi.org/10.1186/1472-6831-11$\underline{27}$

Tickle M, O’ Neill C, Donaldson M, Birch S, Noble S, Killough S, Murphy L, Greer M, Brodison J, Verghis R et al. 2016. A randomised controlled trial to measure the effects and costs of a dental caries prevention regime for young 
children attending primary care dental services: the Northern Ireland Caries Prevention In Practice (NIC-PIP) trial. Health Technol Assess. 20 (71):1-96.

Tickle M, O’Neill C, Donaldson M, Birch S, Noble S, Killough S, Murphy L, Greer M, Brodison J, Worthington HV. 2017. A randomized controlled trial of caries prevention in dental practice. J Dent Res. Apr 1:22034517702330. doi: 10.1177/0022034517702330. [Epub ahead of print]

UK NHS Reference Costs 2013-14. 2015. London: Department of Health; [accessed December 14, 2016]. http://www.gov.uk/ government/collections/nhs-reference-costs\#published-reference-costs 


\begin{tabular}{|l|r|r|r|}
\hline \multicolumn{3}{|c|}{ Table 1. Total costs of care in intervention and control groups } \\
\hline \multicolumn{1}{|c|}{ Intervention } & Control & Mean difference \\
\hline $\begin{array}{l}\text { Average total } \\
\text { direct health } \\
\text { service costs }\end{array}$ & 155.74 & 48.21 & $-107.53 \dagger$ \\
\hline $\begin{array}{l}\text { Average total } \\
\text { indirect health } \\
\text { service cost }\end{array}$ & 831.79 & 726.76 & -105.03 \\
\hline $\begin{array}{l}\text { Average total } \\
\text { parental cost }\end{array}$ & 39.78 & 40.72 & 0.94 \\
\hline $\begin{array}{l}\text { Average total } \\
\text { health care costs } \\
\text { (sum of rows } 1 \\
\text { and 2) }\end{array}$ & 987.53 & 774.97 & $-212.56 \dagger$ \\
\hline $\begin{array}{l}\text { Average total } \\
\text { cost }\end{array}$ & & & \\
\hline
\end{tabular}

note the cost of a check-up was included in the cost for both intervention and control groups †indicates statistically significant difference at $p=0.05$ 
Table 2. Incremental cost effectiveness ratios (ICER)

\begin{tabular}{|l|r|r|}
\hline & Mean & 95\% confidence interval \\
\hline $\begin{array}{l}\text { Mean difference is } \\
\text { mean difference in } \\
\text { proportion caries free }\end{array}$ & -2092.59 & -30100.40 to 27921.80 \\
\hline $\begin{array}{l}\text { Mean difference in } \\
\text { health service cost / } \\
\text { mean difference in } \\
\text { number of carious } \\
\text { surfaces }\end{array}$ & -250.58 & \\
\hline $\begin{array}{l}\text { Mean difference in } \\
\text { health service cost / } \\
\text { mean difference in } \\
\text { number of episodes of } \\
\text { pain }\end{array}$ & & -454.39 to -79.52 \\
\hline $\begin{array}{l}\text { Mean difference is total } \\
\text { costs / mean difference } \\
\text { in proportion caries free }\end{array}$ & -259.07 & -14664.00 to 14941.60 \\
\hline $\begin{array}{l}\text { Mean difference in total } \\
\text { cost / mean difference in } \\
\text { number of carious } \\
\text { surfaces }\end{array}$ & & \\
\hline $\begin{array}{l}\text { Mean difference in total } \\
\text { cost / mean difference in }\end{array}$ & & \\
\hline
\end{tabular}




\begin{tabular}{|l|c|c|}
\hline \multicolumn{3}{|l|}{ Table 3. Net monetary benefit (NMB) per unit of effect } \\
\hline Effect & Mean & $95 \%$ confidence interval \\
\hline $\begin{array}{l}\text { Net monetary benefit } \\
\text { per caries free person }\end{array}$ & $-£ 165.06$ & $-£ 291.04$ to $-£ 44.79$ \\
\hline $\begin{array}{l}\text { Net monetary benefit } \\
\text { per carious surface } \\
\text { avoided }\end{array}$ & $£ 1063.81$ & $£ 298.08$ to $£ 1854.62$ \\
\hline $\begin{array}{l}\text { Net monetary benefit } \\
\text { per episode of pain } \\
\text { avoided }\end{array}$ & $-£ 280.45$ to $£ 36.46$ \\
\hline $\begin{array}{l}\text { Note these are based on bootstrapped NMBs where a threshold of } £ 1000 \text { is } \\
\text { assumed for each outcome }\end{array}$ \\
\hline
\end{tabular}




\section{CE Plane: dTHCC / dcaries}

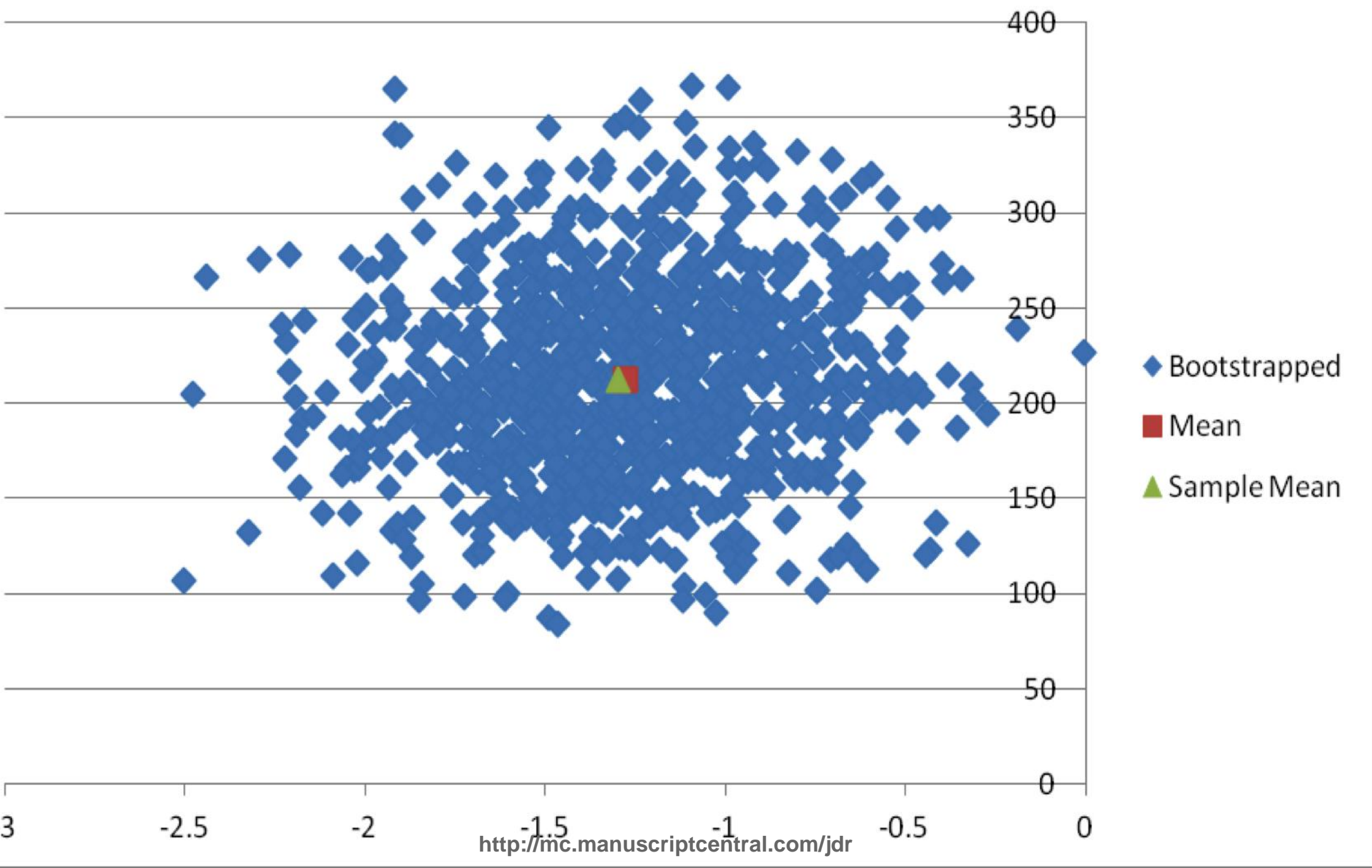




\section{Appendix Title: Cost-effectiveness of caries prevention in practice:} randomized controlled trial

C O'Neill ${ }^{1}$, HV Worthington ${ }^{2}$, M Donaldson $^{3}, \mathrm{~S} \mathrm{Birch}^{4}, \mathrm{~S} \mathrm{Noble}^{5}, \mathrm{~S} \mathrm{Killough}^{6}$, L Murphy $^{7}, \mathrm{M} \mathrm{Greer}^{8}, \mathrm{~J} \mathrm{Brodison}^{9}, \mathrm{R}$ Verghis $^{7}, \mathrm{M} \mathrm{Tickle}^{2}$ 
Allocated to intervention group $(\mathrm{n}=$ 624)

Received allocated intervention at least once $(n=624)$
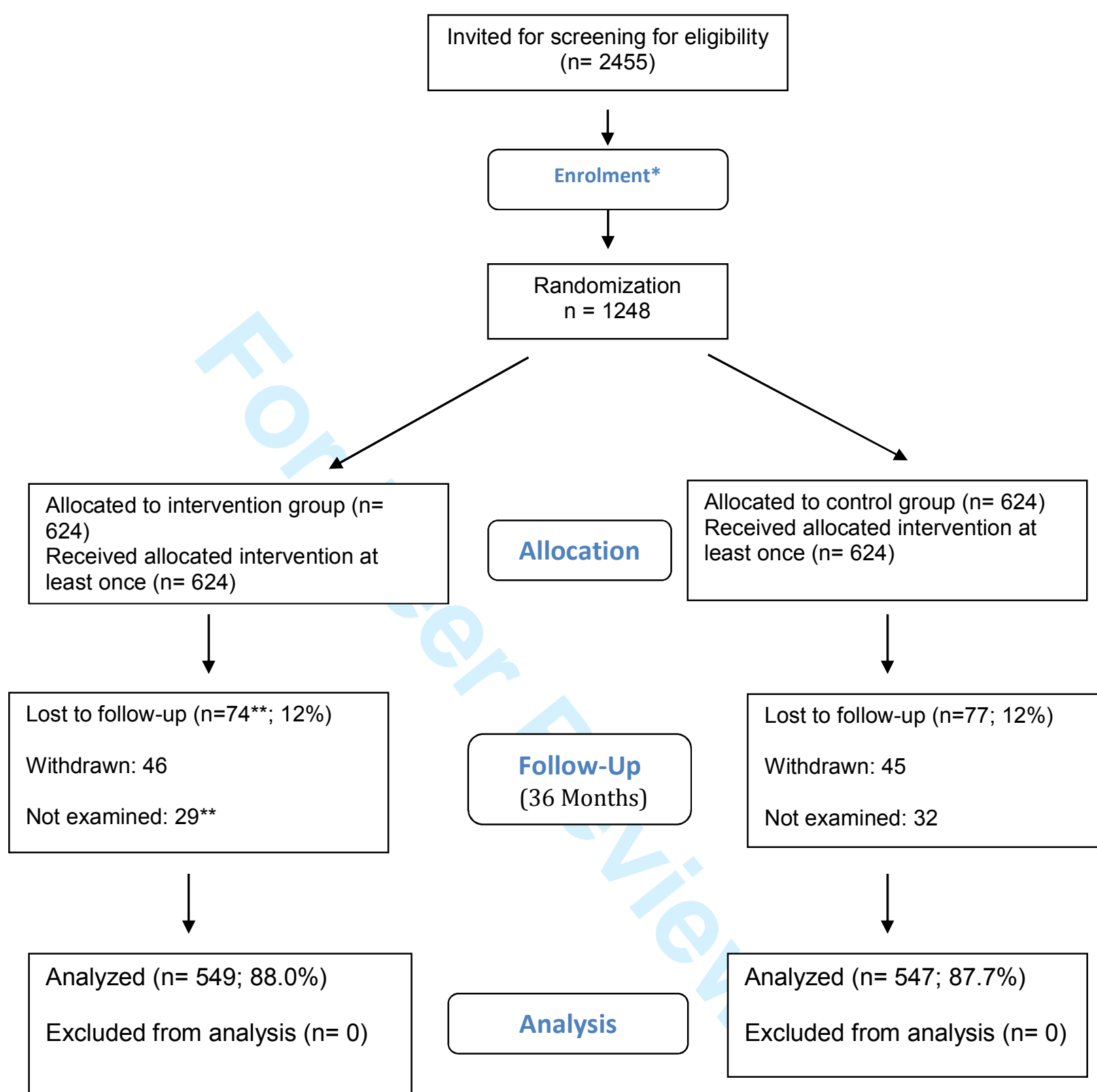

* Not randomised $n=1207(49.2 \%)$

- CDS assessor refusal (36)

- Parent withheld consent (138)

- Did not attend $(\mathrm{n}=758)$

- Ineligible (158): caries (85), age (35), allergies (22), hospitalisation (10), adverse medical history (2), other trial (2), history lactose intolerant (1), not known (1)

- Other reasons (117): patient would no cooperate (64), sibling recruited (16), appointment cancelled (15), parent absent (11), already on trial (3), language barrier (3), family migrating (2), patient sick (2), family left due to appointment (1)

${ }^{* *}$ One child attended but did not have caries exam 


\begin{tabular}{|c|c|c|c|c|c|c|c|c|c|c|c|c|c|}
\hline & $1^{*}$ & 2 & 3 & 4 & 5 & 6 & 7 & 8 & 9 & 10 & 11 & 12 & 13 \\
\hline 1 & $\begin{array}{l}0.947^{* *} \\
(0.013)\end{array}$ & $\begin{array}{l}0.891 \\
(0.018)\end{array}$ & $\begin{array}{l}0.827 \\
(0.023)\end{array}$ & $\begin{array}{l}0.863 \\
(0.020)\end{array}$ & $\begin{array}{l}0.902 \\
(0.017)\end{array}$ & $\begin{array}{l}0.819 \\
(0.022)\end{array}$ & $\begin{array}{l}0.874 \\
(0.018)\end{array}$ & $\begin{array}{l}0.793 \\
(0.022)\end{array}$ & $\begin{array}{l}0.831 \\
(0.022)\end{array}$ & $\begin{array}{l}0.894 \\
(0.017)\end{array}$ & $\begin{array}{l}0.864 \\
(0.019)\end{array}$ & $\begin{array}{l}0.851 \\
(0.020)\end{array}$ & $\begin{array}{l}0.881 \\
(0.018)\end{array}$ \\
\hline 2 & & $\begin{array}{l}0.919 \\
(0.016)\end{array}$ & $\begin{array}{l}0.857 \\
(0.021)\end{array}$ & $\begin{array}{l}0.886 \\
(0.018)\end{array}$ & $\begin{array}{l}0.890 \\
(0.018)\end{array}$ & $\begin{array}{l}0.817 \\
(0.022)\end{array}$ & $\begin{array}{l}0.868 \\
(0.019)\end{array}$ & $\begin{array}{l}0.807 \\
(0.022)\end{array}$ & $\begin{array}{l}0.810 \\
(0.024)\end{array}$ & $\begin{array}{l}0.858 \\
(0.020)\end{array}$ & $\begin{array}{l}0.904 \\
(0.016)\end{array}$ & $\begin{array}{l}0.834 \\
(0.021)\end{array}$ & $\begin{array}{l}0.881 \\
(0.018)\end{array}$ \\
\hline 3 & & & $\begin{array}{l}0.889 \\
(0.019)\end{array}$ & $\begin{array}{l}0.809 \\
(0.024)\end{array}$ & $\begin{array}{l}0.856 \\
(0.021)\end{array}$ & $\begin{array}{l}0.790 \\
(0.025)\end{array}$ & $\begin{array}{l}0.771 \\
(0.025)\end{array}$ & $\begin{array}{l}0.737 \\
(0.025)\end{array}$ & $\begin{array}{l}0.805 \\
(0.025)\end{array}$ & $\begin{array}{l}0.837 \\
(0.022)\end{array}$ & $\begin{array}{l}0.801 \\
(0.024)\end{array}$ & $\begin{array}{l}0.756 \\
(0.025)\end{array}$ & $\begin{array}{l}0.824 \\
(0.023)\end{array}$ \\
\hline 4 & & & & $\begin{array}{l}0.925 \\
0.016\end{array}$ & $\begin{array}{l}0.856 \\
(0.020)\end{array}$ & $\begin{array}{l}0.787 \\
(0.023)\end{array}$ & $\begin{array}{l}0.858 \\
(0.019)\end{array}$ & $\begin{array}{l}0.819 \\
(0.021)\end{array}$ & $\begin{array}{l}0.801 \\
(0.024)\end{array}$ & $\begin{array}{l}0.843 \\
(0.021)\end{array}$ & $\begin{array}{l}0.883 \\
(0.018)\end{array}$ & $\begin{array}{l}0.846 \\
(0.020)\end{array}$ & $\begin{array}{l}0.848 \\
(0.020)\end{array}$ \\
\hline 5 & & & & & $\begin{array}{l}0.955 \\
(0.012)\end{array}$ & $\begin{array}{l}0.838 \\
(0.021)\end{array}$ & $\begin{array}{l}0.861 \\
(0.019)\end{array}$ & $\begin{array}{l}0.790 \\
(0.023)\end{array}$ & $\begin{array}{l}0.884 \\
(0.019)\end{array}$ & $\begin{array}{l}0.899 \\
(0.017)\end{array}$ & $\begin{array}{l}0.857 \\
(0.020)\end{array}$ & $\begin{array}{l}0.838 \\
(0.021)\end{array}$ & $\begin{array}{l}0.892 \\
(0.018)\end{array}$ \\
\hline 6 & & & & & & $\begin{array}{l}0.870 \\
(0.019\end{array}$ & $\begin{array}{l}0.805 \\
(0.022)\end{array}$ & $\begin{array}{l}0.786 \\
(0.022)\end{array}$ & $\begin{array}{l}0.795 \\
(0.025)\end{array}$ & $\begin{array}{l}0.822 \\
(0.021)\end{array}$ & $\begin{array}{l}0.816 \\
(0.021)\end{array}$ & $\begin{array}{l}0.801 \\
(0.022)\end{array}$ & $\begin{array}{l}0.821 \\
(0.021)\end{array}$ \\
\hline 7 & & & & & & & $\begin{array}{l}0.909 \\
(0.016)\end{array}$ & $\begin{array}{l}0.830 \\
(0.020)\end{array}$ & $\begin{array}{l}0.776 \\
(0.024)\end{array}$ & $\begin{array}{l}0.833 \\
(0.021)\end{array}$ & $\begin{array}{l}0.876 \\
(0.018)\end{array}$ & $\begin{array}{l}0.857 \\
(0.019)\end{array}$ & $\begin{array}{l}0.864 \\
(0.019)\end{array}$ \\
\hline 8 & & & & & & & & $\begin{array}{l}0.875 \\
(0.017)\end{array}$ & $\begin{array}{l}0.752 \\
(0.024)\end{array}$ & $\begin{array}{l}0.796 \\
(0.022)\end{array}$ & $\begin{array}{l}0.857 \\
(0.019)\end{array}$ & $\begin{array}{l}0.840 \\
(0.019)\end{array}$ & $\begin{array}{l}0.795 \\
(0.022)\end{array}$ \\
\hline 9 & & & & & & & & & $\begin{array}{l}0.903 \\
(0.018)\end{array}$ & $\begin{array}{l}0.858 \\
(0.020)\end{array}$ & $\begin{array}{l}0.798 \\
(0.024)\end{array}$ & $\begin{array}{l}0.766 \\
(0.024)\end{array}$ & $\begin{array}{l}0.839 \\
(0.021)\end{array}$ \\
\hline 10 & & & & & & & & & & 0.911 & 0.851 & 0.827 & 0.895 \\
\hline
\end{tabular}




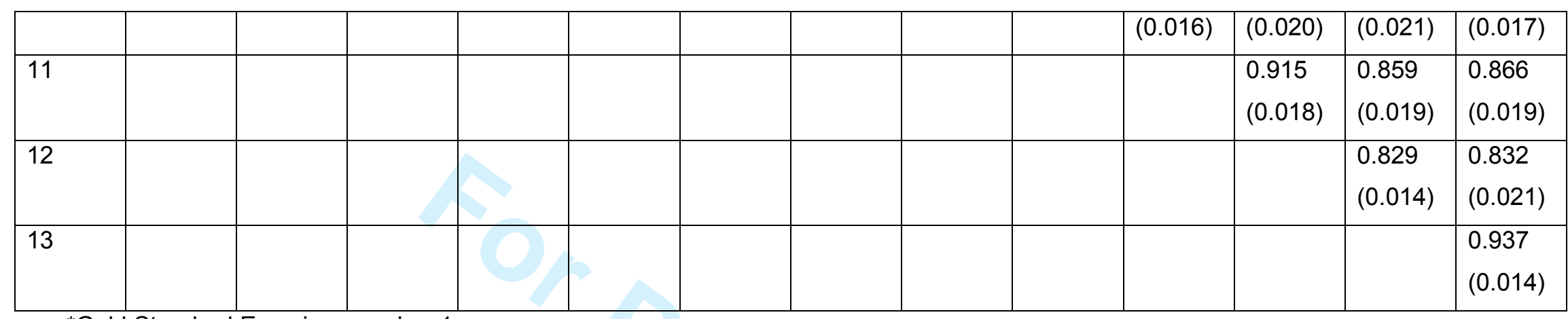

${ }^{*}$ Gold Standard Examiner number 1

**Intra-examiner kappas highlighted in blue

Appendix Table 1 Results calibration prior to outcome assessment: surfaces - kappa statistics and asymptotic standard errors in parenthesis for a) inter -examiner agreement (first visit) and b) intra-examiner agreement (both visits) is shown on the diagonal, for surfaces (25 children; 2200 surfaces at first exam) 


\begin{tabular}{|c|c|c|c|}
\hline & $\begin{array}{l}\text { Intervention Group } \\
(\mathrm{N}=624)\end{array}$ & $\begin{array}{l}\text { Control Group } \\
(\mathrm{N}=624)\end{array}$ & $\begin{array}{l}\text { Total } \\
(\mathrm{N}=1248)\end{array}$ \\
\hline \multicolumn{4}{|l|}{ Gender } \\
\hline Male & $283(45.4 \%)$ & $296(47.4 \%)$ & $597(46.4 \%)$ \\
\hline Female & $341(54.7 \%)$ & $328(52.6 \%)$ & $669(53.6 \%)$ \\
\hline \multicolumn{4}{|l|}{ Age (years) } \\
\hline Mean (s.d) & $3.1(0.53)$ & $3.1(0.53)$ & $3.1(0.53)$ \\
\hline $\begin{array}{l}\text { Median (minimum, } \\
\text { maximum) }\end{array}$ & $3.1(2.0,4.0)$ & $3.0(2.0,4.0)$ & $3.1(2.0,4.0)$ \\
\hline Missing & 0 & 0 & 0 \\
\hline \multicolumn{4}{|l|}{ MDM } \\
\hline $\begin{array}{l}\text { Quintile } 1 \text { (most } \\
\text { deprived) }\end{array}$ & $88(14.1 \%)$ & $106(17.0 \%)$ & $194(15.6 \%)$ \\
\hline Quintile 2 & $141(22.6 \%)$ & $134(21.5 \%)$ & $275(22.1 \%)$ \\
\hline Quintile 3 & $172(27.6 \%)$ & $155(24.9 \%)$ & $327(26.4 \%)$ \\
\hline Quintile 4 & $148(23.8 \%)$ & 155 (24.9\%) & $303(24.3 \%)$ \\
\hline $\begin{array}{l}\text { Quintile } 5 \text { (least } \\
\text { deprived) }\end{array}$ & 74 (11.9\%) & $73(11.7 \%)$ & 147 (11.8\%) \\
\hline Missing & 1 & 1 & 2 \\
\hline
\end{tabular}

Appendix Table 2 Baseline demographic data for all recruited children by study group 


\begin{tabular}{|c|c|c|c|}
\hline & Intervention Group & Control Group & $\%$ reduction \\
\hline \multicolumn{4}{|c|}{ All children } \\
\hline dmfs & 2.45 & $3.74^{* *}$ & 34 \\
\hline dmft & 1.15 & $1.64^{* *}$ & 30 \\
\hline $\mathrm{ft}$ & 0.24 & $0.42^{* *}$ & 43 \\
\hline \multicolumn{4}{|c|}{ Children with caries } \\
\hline dmfs & 7.18 & $9.61^{* *}$ & 25 \\
\hline dmft & 3.39 & $4.20 * *$ & 19 \\
\hline $\mathrm{ft}$ & 0.71 & $1.07^{*}$ & 34 \\
\hline \multicolumn{4}{|c|}{ ** $P<0.01$} \\
\hline
\end{tabular}

Appendix Table 3 Summary of clinical findings for total population and for those children who developed caries. 


\begin{tabular}{|c|c|c|}
\hline Cost item & Cost $(£)$ & Reference \\
\hline $\begin{array}{l}\text { Brushes and } \\
\text { toothpaste per visit }\end{array}$ & 0.4 & $\begin{array}{l}\text { Professor Martin Tickle, } \\
\text { University of Manchester, } \\
2014 \text {, personal communication }\end{array}$ \\
\hline Duraphat per visit & 0.75 & $\begin{array}{l}\text { Professor Martin Tickle, } \\
\text { University of Manchester, } \\
2014 \text {, personal communication }\end{array}$ \\
\hline $\begin{array}{l}\text { Delivery time by dentist } \\
\text { per minute }\end{array}$ & 1.50 & $\begin{array}{l}\text { NI dental survey of adental } \\
\text { earnings }{ }^{1} \text { and }{ }^{b} \text { PSSRU times } \\
2014^{2}\end{array}$ \\
\hline Postage per visit & $\begin{array}{l}0.62, \text { post, } 0.33 \\
\text { time }\end{array}$ & $\begin{array}{l}\text { Assuming a letter with stamps } \\
\text { purchased on line }{ }^{3} \text { and } \\
\text { average NI hourly earnings } \\
\text { with } 2 \text { minutes to post: NI } \\
\text { Annual survey of Hours and } \\
\text { Earnings } 2014^{4} \text { Assumes } \\
\text { median hourly earnings of } £ 10\end{array}$ \\
\hline $\begin{array}{l}\text { Filled surfaces per } \\
\text { filling }\end{array}$ & 8.9 & $\begin{array}{l}\text { Statement of Dental } \\
\text { Remuneration 2014-2015 } \\
(1401)^{5}\end{array}$ \\
\hline $\begin{array}{l}\text { Extractions with LA per } \\
\text { extraction }\end{array}$ & 8.24 & $\begin{array}{l}\text { Statement of Dental } \\
\text { Remuneration 2014-2015 } \\
(2101)^{5}\end{array}$ \\
\hline $\begin{array}{l}\text { Extractions with GA } \\
\text { per extraction }\end{array}$ & 791 & $\begin{array}{l}\text { Mrs Solveig Noble, Clinical } \\
\text { Director of Community Dental } \\
\text { Services, Northern } \\
\text { Health and Social Care Trust, } \\
\text { 2014, personal communication }\end{array}$ \\
\hline $\begin{array}{l}\text { Pulpectomy per } \\
\text { pulpectomy }\end{array}$ & 8.60 & $\begin{array}{l}\text { Statement of Dental } \\
\text { Remuneration 2014-2015 } \\
(4403)^{5}\end{array}$ \\
\hline $\begin{array}{l}\text { Advice/check-up per } \\
\text { consultation }\end{array}$ & 8.34 & $\begin{array}{l}\text { Statement of Dental } \\
\text { Remuneration 2014-2015 } \\
(0101)^{5}\end{array}$ \\
\hline Polish per consultation & 13.23 & $\begin{array}{l}\text { Statement of Dental } \\
\text { Remuneration 2014-2015 } \\
(1001)^{5}\end{array}$ \\
\hline $\begin{array}{l}\text { Other (check-up) per } \\
\text { consultation }\end{array}$ & 8.34 & $\begin{array}{l}\text { Statement of Dental } \\
\text { Remuneration } 2014-2015 \\
(0101)^{5}\end{array}$ \\
\hline GP per consultation & 46 & $\begin{array}{l}\text { PSSRU, assuming } 11.7 \\
\text { minutes }^{2}\end{array}$ \\
\hline Outpatient per episode & 189 & PSSRU, paediatric outpatient $^{2}$ \\
\hline Inpatient per night & 327 & $\begin{array}{l}\text { UK reference costs charge per } \\
\text { day based on excess bed day } \\
\text { charge for elective inpatient }{ }^{6}\end{array}$ \\
\hline A\&E per episode & 124 & UK reference costs $2013 / 14^{6}$ \\
\hline Travel time & 0.167 per minute & $\begin{array}{l}{ }^{\mathrm{C}} \mathrm{NI} \text { Annual survey of Hours } \\
\text { and Earnings } 2014^{4}\end{array}$ \\
\hline
\end{tabular}




\begin{tabular}{|l|l|l|}
\hline Time off work & 0.167 per minute & $\begin{array}{l}{ }^{c} \mathrm{NI} \text { Annual survey of Hours } \\
\text { and Earnings 2014 }\end{array}$ \\
\hline Travel & 0.4804 per mile & $\begin{array}{l}\text { AA total standing and running } \\
\text { costs assuming 15,000 miles } \\
\text { per year, petrol car }\end{array}$ \\
\hline $\begin{array}{l}\text { Delivery time by dental } \\
\text { nurse per minute }\end{array}$ & 0.22 & $\begin{array}{l}\text { British Dental Association } \\
\text { estimate of trained dental } \\
\text { nurse earnings of } £ 8.93 p e r \\
\text { hour }{ }^{8} \text { Adjusted by earnings to } \\
\text { expenses ratio for dentists of } \\
55.4 \%{ }^{2}\end{array}$ \\
\hline $\begin{array}{l}\text { Delivery time by dental } \\
\text { hygienist per minute }\end{array}$ & 0.72 & $\begin{array}{l}\text { British Dental Association } \\
\text { estimate of trained dental } \\
\text { hygienist earnings of } £ 27.76 \\
\text { per hour }{ }^{8} \text { Adjusted by earnings } \\
\text { to expenses ratio for dentists } \\
\text { of } 55.4 \%{ }^{2}\end{array}$ \\
\hline
\end{tabular}

AA, Automobile Association; LA, local anaesthetic; PSSRU, Personal Social Services Research Unit.

a Average gross earnings of all self-employed GDS dentists in Northern Ireland, including overheads of $£ 160,400$.

b Estimate based on 43.4 weeks, 41-hour week. c Assumes median hourly earnings of $£ 10$.

${ }^{1}$ Dental Earnings and Expenses 2012/2013 Initial Analysis. Average gross earnings of all self-employed GDS dentists in Northern Ireland including overheads of $£ 160,400$.

http://www.hscic.gov.uk/catalogue/PUB14920/dent-earn-expe-2012-13-initrep.pdf (accessed August 2015)

${ }^{2}$ Unit Costs of Health and Social Care, 2014. PSSRU. Estimate based on 43.4 weeks, 41 hour week.

http://www.pssru.ac.uk/project-pages/unit-costs/2014/ (accessed August 2015)

${ }^{3}$ Royal Mail "Our Prices" http://www.royalmail.com/sites/default/files/RM OurPrices Mar2014a.pdf (accessed August 2015)

${ }^{4}$ Northern Ireland Annual Survey of Hours and Earnings November 2014. https://www.detini.gov.uk/index/what-we-do/deti-statsindex/labour market statistics/stats-hours-and-earnings/ashe tables.htm (accessed August 2015)

${ }^{5}$ Statement of Dental Remuneration 2014-15.

http://www.hscbusiness.hscni.net/pdf/STATEMENT OF DENTAL REMUNE RATION 2014 -15.pdf (accessed August 2014) ${ }^{6}$ UK reference costs https://www.gov.uk/government/collections/nhs-reference-costs\#publishedreference-costs (accessed August 2015) 
${ }^{7}$ https://www.theaa.com/resources/Documents/pdf/motoring-advice/runningcosts/petrol2014.pdf

(accessed August 2014)

${ }^{8}$ https://www.bda.org/dentists/policy-campaigns/research/workforce-

finance/dcps/dcp-pay-surveys

(accessed August 2015)

Appendix Table 4 Source details of unit costs 


\begin{tabular}{|c|c|c|c|c|c|c|}
\hline & \multicolumn{3}{|c|}{ Intervention $\mathrm{N}=549$} & \multicolumn{3}{|c|}{ Control $\mathrm{N}=547$} \\
\hline Activity/Consumable & $\begin{array}{l}\text { Mean } \\
\text { cost }\end{array}$ & $\begin{array}{l}\text { Standard } \\
\text { deviation }\end{array}$ & Skewness & $\begin{array}{l}\text { Mean } \\
\text { cost }\end{array}$ & $\begin{array}{l}\text { Standard } \\
\text { deviation }\end{array}$ & Skewness \\
\hline $\begin{array}{l}\text { Brushes and } \\
\text { toothpaste }\end{array}$ & 2.40 & 0 & - & 0 & 0 & - \\
\hline Delivery time & 94.81 & 26.44 & 0.88 & 0 & 0 & - \\
\hline Flouride varnish & 4.36 & 0.42 & -3.86 & 0 & 0 & - \\
\hline $\begin{array}{l}\text { Postage including } \\
\text { time }\end{array}$ & 5.70 & 0 & - & 0 & 0 & - \\
\hline $\begin{array}{l}\text { Cost of check-up at } \\
\text { which varnish is } \\
\text { applied }\end{array}$ & 48.48 & 4.64 & -3.86 & & & \\
\hline Intervention & 155.74 & 26.60 & 0.85 & 48.21 & $4.76^{\circ}$ & -2.94 \\
\hline
\end{tabular}

"The "intervention" in respect of the control group related to 6 monthly checkups offered to participants in the study. Mean cumulative delivery time per child was 63.21 minutes with a standard deviation of 17.63 minutes.

Appendix Table 5 Direct dental healthcare costs 


\begin{tabular}{|c|c|c|c|c|c|c|}
\hline Activity & \multicolumn{2}{|c|}{ Intervention } & \multicolumn{2}{|l|}{ Control } & \multirow[b]{2}{*}{$\begin{array}{l}\text { Mean } \\
\text { diff in } n\end{array}$} & \multirow[b]{2}{*}{$\begin{array}{l}\text { Mean } \\
\text { diff in } \mathrm{C}\end{array}$} \\
\hline DENTAL & $\begin{array}{l}\text { Mean } \\
\text { no. }\end{array}$ & $\begin{array}{l}\text { Mean } \\
\text { cost }\end{array}$ & $\begin{array}{l}\text { Mean } \\
\text { no. }\end{array}$ & $\begin{array}{l}\text { Mean } \\
\text { cost }\end{array}$ & & \\
\hline $\begin{array}{l}\text { Non-intervention } \\
\text { related visits to } \\
\text { trial dentist }\end{array}$ & 1.88 & 29.11 & 2.38 & 32.03 & $0.50 \dagger$ & 2.92 \\
\hline $\begin{array}{l}\text { Non-intervention } \\
\text { related visits to } \\
\text { other dentists }\end{array}$ & 0.09 & 0.79 & 0.11 & 0.93 & 0.02 & 0.14 \\
\hline No. of fillings & 0.68 & 6.01 & 1.02 & 9.08 & $0.34 \dagger$ & $3.06^{*}$ \\
\hline $\begin{array}{l}\text { No. of extractions } \\
\text { with injections }\end{array}$ & 0.01 & 0.09 & 0.12 & 0.95 & $0.10 \dagger$ & $0.86^{*}$ \\
\hline $\begin{array}{l}\text { No of extractions } \\
\text { with GA }\end{array}$ & 0.016 & 12.97 & 0.015 & 11.57 & -0.002 & -1.40 \\
\hline $\begin{array}{l}\text { No of other } \\
\text { procedures }\end{array}$ & 1.19 & 10.06 & 1.25 & 10.49 & 0.05 & 0.43 \\
\hline NON-DENTAL & Interve & & Contro & & & \\
\hline & $\begin{array}{l}\text { Mean } \\
\text { no. }\end{array}$ & $\begin{array}{l}\text { Mean } \\
\text { cost }\end{array}$ & $\begin{array}{l}\text { Mean } \\
\text { no. }\end{array}$ & $\begin{array}{l}\text { Mean } \\
\text { cost }\end{array}$ & $\begin{array}{l}\text { Mean } \\
\text { diff in } n\end{array}$ & $\begin{array}{l}\text { Mean } \\
\text { diff in c }\end{array}$ \\
\hline No GP visits & 9.04 & 416.01 & 8.75 & 402.65 & 0.29 & -13.36 \\
\hline $\begin{array}{l}\text { No. outpatient } \\
\text { visits }\end{array}$ & 0.70 & 131.51 & 0.40 & 76.01 & 0.29 & -55.49 \\
\hline No. Inpatient days & 0.34 & 109.60 & 0.21 & 69.94 & -0.12 & -39.65 \\
\hline No. of $A \& E$ visits & 1.17 & 144.76 & 1.17 & 145.14 & 0.00 & 0.38 \\
\hline
\end{tabular}

Appendix Table 6 Indirect healthcare costs 


\begin{tabular}{|l|l|l|l|}
\hline & Intervention & Control & Mean difference \\
\hline $\begin{array}{l}\text { Average travel } \\
\text { time to trial } \\
\text { dentist (minutes) }\end{array}$ & 166.57 & 169.28 & 2.71 \\
\hline $\begin{array}{l}\text { Average travel } \\
\text { time to other } \\
\text { dentists* } \\
\text { (minutes) }\end{array}$ & 1.27 & 2.29 & 1.02 \\
\hline $\begin{array}{l}\text { Average distance } \\
\text { to trial dentist } \\
\text { (miles) }\end{array}$ & 32.25 & 34.20 & 1.96 \\
\hline $\begin{array}{l}\text { Average distance } \\
\text { to other dentists* } \\
\text { (miles) }\end{array}$ & 0.65 & 0.87 & 0.22 \\
\hline $\begin{array}{l}\text { Average time } \\
\text { taken off work to } \\
\text { visit trial dentist } \\
\text { (minutes) }\end{array}$ & 139.19 & 137.24 & -1.95 \\
\hline $\begin{array}{l}\text { Average time } \\
\text { taken off work to } \\
\text { visit other } \\
\text { dentists (minutes) }\end{array}$ & 4.34 & 5.65 & 1.30 \\
\hline
\end{tabular}

${ }^{*}$ imputed based on reported travel and activity to trial dentists and reported distance and activity to non-trial dentists

Appendix Table 7 Parental activity associated with dental healthcare of their children 


\begin{tabular}{|c|c|c|}
\hline Costs $(£)$ & Mean & 95\% confidence interval \\
\hline $\begin{array}{l}\text { Mean difference in } \\
\text { health service } \\
\text { costs/mean difference in } \\
\text { proportion caries free }\end{array}$ & -2514.37 & $-24,313.00$ to $17,617.10$ \\
\hline $\begin{array}{l}\text { Mean difference in } \\
\text { health service } \\
\text { cost/mean difference in } \\
\text { number of carious } \\
\text { surfaces }\end{array}$ & -150.25 & -338.87 to -50.32 \\
\hline $\begin{array}{l}\text { Mean difference in } \\
\text { health service } \\
\text { cost/mean difference in } \\
\text { number of episodes of } \\
\text { pain }\end{array}$ & -2030.53 & $-13,031.80$ to 7989.71 \\
\hline $\begin{array}{l}\text { Mean difference in total } \\
\text { costs/mean difference in } \\
\text { proportion caries free }\end{array}$ & -2494.17 & $-24,586.60$ to $17,856.90$ \\
\hline $\begin{array}{l}\text { Mean difference in total } \\
\text { cost/mean difference in } \\
\text { number of carious } \\
\text { surfaces }\end{array}$ & -149.48 & -337.06 to -50.06 \\
\hline $\begin{array}{l}\text { Mean difference in total } \\
\text { cost/mean difference in } \\
\text { number of episodes of } \\
\text { pain }\end{array}$ & -2017.56 & $-13,130.80$ to 7912.04 \\
\hline
\end{tabular}

Appendix Table 8 Sensitivity analysis using measured time to provide the intervention: ICERs 


\begin{tabular}{|l|l|l|}
\hline $\begin{array}{l}\text { Effect } \\
\text { NMB per caries-free } \\
\text { person }\end{array}$ & -120.70 & $95 \%$ confidence interval \\
\hline $\begin{array}{l}\text { NMB per carious } \\
\text { surface avoided }\end{array}$ & 1118.95 & -243.92 to -4.47 \\
\hline $\begin{array}{l}\text { NMB per episode of } \\
\text { pain avoided }\end{array}$ & -64.63 & 399.16 to 1863.53 \\
\hline
\end{tabular}

Note: These figures are based on bootstrapped NMBs for which a threshold of $£ 1000$ is assumed for each outcome

Appendix Table 9 Sensitivity analysis using measured time to provide the intervention: NMB $(£)$ per unit of effect 


\section{CONSORT 2010 checklist of information to include when reporting a randomised trial*}

\begin{tabular}{|c|c|c|}
\hline Section/Topic & $\begin{array}{c}\text { Item } \\
\text { No }\end{array}$ & Checklist item \\
\hline \multicolumn{3}{|l|}{ Title and abstract } \\
\hline & $1 a$ & Identification as a randomised trial in the title \\
\hline & $1 \mathrm{~b}$ & Structured summary of trial design, methods, results, and conclusions (for specific guidance see CONSORT for abstracts) \\
\hline \multicolumn{3}{|l|}{ Introduction } \\
\hline Background and & $2 a$ & Scientific background and explanation of rationale \\
\hline objectives & $2 b$ & Specific objectives or hypotheses \\
\hline
\end{tabular}

\section{Methods}

Trial design

3a Description of trial design (such as parallel, factorial) including allocation ratio

Participants

$3 b$

Important changes to methods after trial commencement (such as eligibility criteria), with reasons

4a Eligibility criteria for participants

$4 \mathrm{~b} \quad$ Settings and locations where the data were collected

Interventions

The interventions for each group with sufficient details to allow replication, including how and when they were actually administered

Outcomes

$6 a$

Completely defined pre-specified primary and secondary outcome measures, including how and when they were assessed

Sample size

$6 \mathrm{~b}$ Any changes to trial outcomes after the trial commenced, with reasons

7a How sample size was determined

$7 \mathrm{~b}$ When applicable, explanation of any interim analyses and stopping guidelines

Reported

on page No

\section{Randomisation:}

Sequence generation

Allocation concealment mechanism Implementation

8a Method used to generate the random allocation sequence

$8 \mathrm{~b}$ Type of randomisation; details of any restriction (such as blocking and block size)

9 Mechanism used to implement the random allocation sequence (such as sequentially numbered containers), describing any steps taken to conceal the sequence until interventions were assigned

10 Who generated the random allocation sequence, who enrolled participants, and who assigned participants to interventions

Blinding

11a If done, who was blinded after assignment to interventions (for example, participants, care providers, those

1

2

$\frac{4}{4}$

5

\begin{tabular}{l}
\hline 5 \\
\hline 5 \\
\hline 5 \\
\hline $5-6$
\end{tabular}

6,7

\begin{tabular}{l}
\hline 6 \\
\hline 6 \\
\hline N\A \\
\hline
\end{tabular}

\begin{tabular}{l}
5 \\
\hline 5 \\
\hline 5
\end{tabular}

5,6

6 


\section{Baseline data} Numbers analysed

Outcomes and estimation

Ancillary analyses

Harms

\section{Discussion}

Limitations Generalisability Interpretation assessing outcomes) and how

$11 \mathrm{~b}$ If relevant, description of the similarity of interventions

12a Statistical methods used to compare groups for primary and secondary outcomes

$12 \mathrm{~b}$ Methods for additional analyses, such as subgroup analyses and adjusted analyses

13a For each group, the numbers of participants who were randomly assigned, received intended treatment, and were analysed for the primary outcome

For each group, losses and exclusions after randomisation, together with reasons

14a Dates defining the periods of recruitment and follow-up

14b Why the trial ended or was stopped

15 A table showing baseline demographic and clinical characteristics for each group

16 For each group, number of participants (denominator) included in each analysis and whether the analysis was by original assigned groups

$17 a$ For each primary and secondary outcome, results for each group, and the estimated effect size and its precision (such as $95 \%$ confidence interval)

$17 \mathrm{~b}$ For binary outcomes, presentation of both absolute and relative effect sizes is recommended

18 Results of any other analyses performed, including subgroup analyses and adjusted analyses, distinguishing pre-specified from exploratory

19 All important harms or unintended effects in each group (for specific guidance see CONSORT for harms)

20 Trial limitations, addressing sources of potential bias, imprecision, and, if relevant, multiplicity of analyses

21 Generalisability (external validity, applicability) of the trial findings

22 Interpretation consistent with results, balancing benefits and harms, and considering other relevant evidence

23 Registration number and name of trial registry

\begin{tabular}{l}
\hline 5 \\
\hline $8-9$ \\
\hline $8-9$ \\
\hline
\end{tabular}

Consort

diagram

Appendix

Consort

diagram

Appendix

Foot note in

Consort

diagram

Appendix

N\A

Appendix

Need the

numbers

\section{$23,24,25$}

\section{$\mathrm{N} \backslash \mathrm{A}$}

Appendix

\section{Reference} clinical paper

\begin{tabular}{l}
14,15 \\
\hline $14-17$ \\
\hline 17 \\
\hline
\end{tabular}
1 
18

*We strongly recommend reading this statement in conjunction with the CONSORT 2010 Explanation and Elaboration for important clarifications on all the items. If relevant, we also recommend reading CONSORT extensions for cluster randomised trials, non-inferiority and equivalence trials, non-pharmacological treatments, herbal interventions, and pragmatic trials. Additional extensions are forthcoming: for those and for up to date references relevant to this checklist, see www.consort-statement.org. 